http://dx.doi.org/10.12775/szhf.2018.035

\author{
JOANNA USAKIEWICZ \\ University of Białystok, BiAŁYstok, Poland \\ E-MAIL: JOANNA.USAKIEWICZ@ONET.EU \\ JERZY KOPANIA \\ E-MAIL: JERZYKOPANIA@O2.PL
}

\title{
Polish Translation of Gassendi's Polemic with Descartes. Description of the Completed Research Project
}

The completion of the following research project involved translating into Polish the work by Pierre Gassendi Disquisitio metaphysica, which is a polemic with René Descartes' Meditations on First Philosophy. ${ }^{1}$ The description consists of the aim of the project, translation methodology as well as the content summary and the major theses of the introduction to the translation.

The project was financed by the National Science Centre under the decision DEC-2013/09/B/HS1/01994. The Centre, based in Cracow, finances original research, i.e. experimental or theoretical research which is to produce new knowledge without aiming at immediate commercial application. This project was completed within the years 2014-2017.

\footnotetext{
${ }^{1}$ This work has been carried out thanks to the support of the National Science Centre (Poland), grant: DEC-2013/09/B/HS1/01994.
} 


\section{Origin and aim of translation}

In the Polish humanities Pierre Gassendi (1592-1655) is associated primarily with his polemic against René Descartes' Meditations on First Philosophy. Of all prolific lifework only a small portion was translated into Polish in 1964, namely a modest part of the treatise Syntagma philosophicum - the introduction (devoted to philosophy) and the first part (devoted to the theory of cognition and logic). ${ }^{2}$ The edition contains the introduction by Leszek Kołakowski ${ }^{3}$ which has so far been the only overall discussion of Gassendi's philosophy in Polish.

By contrast, Polish reception of René Descartes' thought has fared much better. All philosophical treatises and a number of natural science writings by the father of modern rationalism have been translated into Polish. Moreover, both his lifework and its various aspects have been discussed in numerous works. His fundamental work Meditations on First Philosophy has three translations, including one from French. The author of the 1948 translation was Maria Ajdukiewicz, the wife of one of the most prominent contemporary Polish philosophers, Kazimierz Ajdukiewicz. This translation, at present considered classical, is officially attributed to both of them.

Ten years later, in 1958, the new translation was extended to include all Objections to the Meditations and all Descartes' Replies (translated by Stefan Swieżawski), the preceding Letter to the Dean and Doctors of the Sacred Faculty of Theology of Paris, and the so called Conversation with Burman (both translated by Izydora Dąmbska). In the introduction, the editors note that the volume doesn't include certain seminal works which contribute to the discussion of the Meditations, namely (1) Gassendi's Disquisitio metaphysica (only its small part is presented in Fifth Set of Objections); (2) Dubitationum et Instantiarum Index, including a detailed table of content of the Disquisitio; (3) Descartes' letter to Clerselier of January 12, 1646, pertaining to Gassendi's new objections; (4) a correspondence in reference to the objections of an anonymous critic, Hyperaspistes; (5) a correspondence in reference to the objections by Henry More; (6) and finally Descartes' letter to Gisbert Voetius.

\footnotetext{
${ }^{2}$ Pierre Gassendi, Logika, w przekładzie Ludwika Chmaja, z dodaniem Wstępu do Zarysu filozofii, w przekładzie Leona Joachimowicza (Warszawa: PWN, 1964).

${ }^{3}$ Leszek Kołakowski, „Piotr Gassendi. Chrześcijanin, materialista, sceptyk”, in Gassendi, Logika, VII-LVIII.
} 
The editors' implicit suggestion was that translating those texts into Polish would be a worthwhile project.

The idea took forty years to emerge as realistic. Before it happened, the translation of an exchange of letters between Descartes and Princess Elisabeth as well as the translation of a correspondence between Descartes and Regius which included a polemic treatise Notae in programma had been prepared at the University of Białystok. Both were translated by Jerzy Kopania and published in 1995 and 1996 in the influential "Biblioteka Klasyków Filozofii" [Classics of Philosophy] series. It therefore seemed only natural that further translations of polemic texts around the Meditations were undertaken. Joanna Usakiewicz translated Descartes' substantial letter to Voetius. ${ }^{4}$ The rendering has been completed for Descartes' four-hundredth anniversary. It was published two years later, in 1998, in the "Biblioteka Klasyków Filozofii" series. Next followed the 2005 collection by Jerzy Kopania entitled Zarzuty i odpowiedzi późniejsze. ${ }^{5}$ It included the exchange of letters between Descartes and Hyperaspistes, Antoine Arnauld and Henry More. The volume was published by "Antyk" in the "Biblioteka Europejska" [the European Library] series. Both editions were complete with introductions and bibliographical notes. Now the full project only needed translations of Disquisitio metaphysica and related to it texts.

The translation of the Disquisitio and Dubitationum et Instantiarum Index was done by Joanna Usakiewicz. It was supplemented by Jerzy Kopania's Polish translation of various French polemic writings. This included Descartes' statement concerning Gassendi's critique and his letter to Clerselier about the summary of the Disquisitio. Additionally, it presents Clerselier's letter and his explanation why, over Descartes' objections, he decided to translate into French Gassendi's Fifth Set of Objections. Jerzy Kopania contributes an extensive introduction which discusses Gassendi's intellectual biography and his philosophical thought. All translations provide bibliographical notes which help to identify numerous citations, biblical and literary allusions and they also explain certain aspects of ancient Greek culture and Catholic dogmas. The volume was published in 2017 by "Wydawnictwo Marek Derewiecki",

${ }^{4}$ René Descartes, List do Voetiusa, tłum. Joanna Usakiewicz (Warszawa: Wydawnictwo Naukowe PWN, 1998).

${ }^{5}$ René Descartes, Zarzuty i odpowiedzi późniejsze. Korespondencja z Hyperaspistesem, Arnauldem i More’em, tłum. Jerzy Kopania (Kęty: Wydawnictwo Antyk, 2005). 
a successor of "Antyk", in the "Biblioteka Europejska" series, which continues the traditions established by the "Biblioteka Klasyków Filozofii". 6

Finally, the Polish translation of the Disquisitio with its related writings completes the polemic texts around the Meditations. At the same time it offers Polish readers a complete selection of the seventeenth-century works which is nowhere to be found in English, French, German or other less popular European languages.

\section{Translation methodology}

This rendering of the Disquisitio uses one of editions of Petri Gassendi Opera omnia in sex tomos divisa (Lugduni, Sumptibus Laurentii Anisson \& Joannis Baptistae Devenet, 1658, vol. III) whereas other writings are based on Oeuvres de Descartes (ed. Ch. Adam and P. Tannery, Paris, Leopold Cerf, 1904, vol. VII and vol. IX-a). The authors intended to retain Gassendi's literary mannerism that was close to the scholasticism. This was often problematic given the intricacies of his idiosyncratic style, but on the other hand, it needed a rendering comprehensible for the contemporary reader.

Gassendi composed his Disquisitio metaphysica in the following way. He first recounts a fragment of his objections Obiectiones quintae to the Meditations in the form of the numbered Dubitatio. It is followed by a suitable part from Descartes' Responsio authoris ad Quintas obiectiones referred to as the Responsio. The subsequent part is the extensive and detailed Instantia, which is divided into numbered sections. As was mentioned earlier, Gassendi's Obiectiones and Descartes' Responsio were translated by Stefan Swieżawski and published together with the Meditations. This new rendering does not aim at surpassing the first classical translation, but it seemed crucial given the linguistic cohesion of the philosopher's discourse. In addition, its most substantial part Instantiae includes Gassendi's own explanations of certain philosophical questions as well as individual lexical terms, which Swieżawski could not possibly have considered without confronting Disquisitio metaphysica.

${ }^{6}$ Pierre Gassendi, Dociekania metafizyczne, czyli wątpliwości i zastrzeżenia wobec metafizyki René Descartes'a i wobec jego odpowiedzi, tłum. Joanna Usakiewicz (Kęty: Wydawnictwo Marek Derewiecki, 2017). 
It is interesting to note that each new rendering entails a certain degree of translator's own interpretation which results from the very process of reading and understanding. ${ }^{7}$ For instance, Swieżawski's rendering seems to overuse the counterfactual conditional mood where, in fact, Gassendi expresses possibility. The translator may be correct in reading the philosopher's views but he seems to lose Gassendi's idiosyncratic way of communication. Writing in modus potentialis, after all, expresses openness to discussion and acquisition of knowledge, which Gassendi often mentions himself. The new translation provides a commentary on certain errors found in the first translation without limiting itself to spelling only.

It is further important to explain the very title of Gassendi's polemic treatise. The Latin word disquisitio means disquisition, investigation, enquiry in English. Polish two words badanie and dociekanie carry similar meaning. While badanie corresponds with investigation, the latter term dociekanie, which might seem a bit anachronistic to a Polish contemporary reader, indicates the act of searching. The second word was selected for the reason that the former one could indicate independent and systematic inquiry on the part of Gassendi, which is not the case here. Gassendi's polemic meticulously questions and comments on Descartes' views and it thoroughly develops the author's own objections which intersect with his metaphysics. Gassendi doesn't necessary want to examine Descartes' outlook, rather he attempts to understand it and show what it indicates. The translation uses a plural form of Polish word dociekania (investigations) for Latin disquisitio which is singular. The reason for this choice was simply aesthetic. It also seemed to resonate better within the context of Polish philosophical writings than the direct translation of disquisition to a singular form dociekanie (investigation).

\footnotetext{
7 The rhetorical and linguistic aspects of Descartes' polemic language have already been the subject of interest of Joanna Usakiewicz. Vide Joanna Usakiewicz, „Problem uczciwości retorycznej i odpowiedzialności za słowo w praktyce polemicznej René Descartesa’, Przegląd Humanistyczny 1 (346), Rok XLII, (1998): 137-148, and also eadem, „Polemiczna łacina Descartes'a na podstawie Listu do Voetiusa", Meander 72 (2017): 33-66.
} 


\section{Introduction to translation}

As it has been already mentioned, Pierre Gassendi seems to be hardly known in Polish humanities and his name connotes merely his polemic with Descartes. It justifies the need to present the philosopher's intellectual biography, life work and academic achievements. It is also worth to show Gassendi's arguments against Cartesian thought from its philosophical background. In his seventy-page long introduction Jerzy Kopania ${ }^{8}$ refers to classical philosophical analyses by such authors as Louis Mandon, Bernard Rochot, Louis Andrieux, Raymond Collier, Alexandre Koyré, John Stevenson Spink, Olivier René Bloch and to the newest writings by, for instance, Thierry Bedouelle, Charles Jacques Beyer, Barry Brundell, Saul Fisher, Howard Jones, Lynnn Sumida Joy, Thomas M. Lennon, Antonia LoLordo, Jean-Michel Maldamé, Sylvia Murr, Margaret J. Osler, Lisa T. Sarasohn, Sylvie Taussig, among others. Gassendi is portrayed here as a unique thinker who indented to proceed with his project of unifying physics, ethics and theology. While it cannot be denied that Gassendi's influence could not match that of Galileo, Descartes or Newton, his physics based on the corpuscular theory of matter constituted an anti-Aristotelian shift in understanding being and became part of modern scientific revolution. Similarly, his philosophical thought remained less influential than Descartes', but this sensorybased, empirical and nominalist philosophy did afford an alternative for those who did not engage in idealism and nativism of his rival.

The introduction highlights the core of the philosophical discord between Gassendi and Descartes and expounds the impossibility of consensus. In Fifth Set of Objections, Gassendi challenges his opponent in three ways which show their everlasting disparity. First, Gassendi rejects the concept of innate ideas; all ideas, including infinity and even God, are derived exclusively from senses. Next, he questions the clarity and distinctness criterion of true cognition, claiming subjectivity instead. His third challenge asserts that the knowledge of the soul can only be indirect, through the body; hence the proposition that the soul may be a subtle invisible sub-

\footnotetext{
${ }^{8}$ Part of the introduction, discussing the attitude of Descartes in a dispute with Gassendi, appeared earlier in the form of an article: Jerzy Kopania, "O powodach irytacji Kartezjusza stanowiskiem Gassendiego", Idea. Studia nad struktura i rozwojem pojęć filozoficznych XXVII (2015): 13-40.
} 
stance. Descartes thought such views utterly disparate from his own and therefore fundamentally wrong and unacceptable. In his line of thinking Gassendi merely echoed futile and commonplace cognition. For him a man who advanced sensory cognition over the Cartesian cogito could not recognize his innovative philosophy and was quite incapable of philosophical thinking.

Descartes was aware of the freshness of his views and theories in philosophical discourse but above all in natural science and medicine. By choosing self-awareness as a point of departure for his meditations on reality he set up new ways of thinking. He asserted that the mind and body were distinct while the latter remained autonomous in action. This claim allowed legitimate and practical studying of the natural world. As it follows, such views invalidated authentic unanimity between himself and the vast majority whose thinking was limited to sensory vision of the world. Descartes had little patience for his opponents and did not suffer easily those who perceived reality in a manner disparate from his own. He considered Gassendi as incapable of exceeding the limited sensory-based perception. To such an extent did they differ in their visions that any form of mutual understanding was impossible.

In a similar way, Gassendi fails to notice that the diversity of opinions stems from their unique visions of the world. Instead he sees it as erroneous thinking. If Descartes assumes that genuine knowledge comes from autonomous reasoning while Gassendi supports sensory-based cognition, then one of them must be mistaken. In Gassendi's opinion, it is Descartes who is in the wrong. The true reasoning leads from objects to the human mind, and Gassendi frequently voices this proposition in the Disquisitio. It further bears upon his critical methods. Gassendi forsakes any attempts to contradict Descartes' theses, and instead concentrates on attacking his opponent's excessively sensitive reactions to criticism. Instead of exhibiting the falseness of opponent's statements from a critical perspective, he decides to reveal that these statements have been announced with the logically incorrect justification or without any justification at all. In other words, in the belief that his own theories were right, Gassendi did not waste time in testing Descartes' accuracy but began to undermine the validity of logical argument.

Nonetheless, the philosopher's polemic with Descartes does not articulate Gassendi's system. To understand his stance in the controversy between the philosophers, one does not need to know Gassendi's philosophy, his theory 
of atomism, attitude towards Epicurus, or understanding of mechanics. But the Disquisitio clearly manifests his epistemology. Gassendi does not set his philosophy against Descartes'; the Mediations, after all, did not invite such contrast. His arguments are based solely on his own unique understanding of the world. For this reason, the polemic has great cognitive value: their mutual indignation allows us to grasp the essence of Cartesian thought. Finally, the conflict allows some insight into the nature of philosophy. This insoluble controversy is a reminder that any great philosophical system is in fact the rationalisation of its author's individual perception of the world. It leaves us with following questions: To what extent may a sophisticated philosophy lead us to discover the nature of the world and a human being? How closely related are the attempts to grasp the essence of reality with human limitations of a thinker? In other words, to what degree can a philosopher see the true nature of things?

A question worth asking is whether this polemic between Gassendi and Descartes warrants the everlasting dissonance between great philosophers. The publication of the Disquisitio is followed by years of grievances and antagonism. And yet, what seemed impossible was finally achieved. When Descartes came to France in family matters in 1648 and visited Paris, there was a meeting between them, as it turned out, the last. And their last meeting has a symbolic dimension. We cannot know what was said at this visit. One can only speculate and hope, however, that reconciliation of some sort took place and that both philosophers attributed their fundamental differences not to their inaccurate reasoning but to their disparate characters. They might have accepted the fact that each would have his followers but that it should not encourage animosity. That would have meant that they recognized their own greatness. It is true that in history Gassendi comes second to the most prominent philosophical mind, Descartes. But just like comparing Plato's and Aristotle's greatness seems futile, we must conclude that Descartes and Gassendi are fundamentally different but they are equal though opposed.

The Sophist, Platonic dialogue (246a-d) says that philosophers argue about what beings really exist. One party of the debate claims that only material substances really "are"; the other, by contrast, grants real existence only to non-material ideas reachable through intelligence. So sharp is this dissonance that Plato calls it the gigantomachy, the mythical battle fought between the giants and the Olympian gods for supremacy of the cosmos. Thomas M. Lennon, American historian of philosophy, used the 
myth to symbolize the controversy between Gassendi and Descartes. ${ }^{9}$ The seventeenth-century empiricist, Gassendi, he argues, could be seen as the leader of the giants while idealistic Descartes would lead the gods. The giants included, for instance, John Locke; the gods, among others, Nicolas Malebranche. The Greek mythology holds that the gods won the battle, and on the philosophical plain many support this claim. Alfred N. Whitehead even asserted that the whole philosophy consists of nothing but footnotes to Plato's idealistic vision. It does not seem, however, that this struggle of philosophical cognitive rationalism with philosophical cognitive sensuality could end in the ultimate victory of one of the parties. Rather than echo the Plato-Aristotle contention, contemporary philosophical debate seems to resonate more with the views of Descartes and Gassendi, and is likely to continue as long as people philosophize in search of the nature of things.

The research project aimed at completing Polish translation of the corpus of writings concerning the Meditations on First Philosophy by René Descartes. Its other goal was to introduce into Polish philosophical studies the works of Pierre Gassendi. We hope that the Polish translation of Disquisitio metaphysica will inspire and encourage scholars in Poland to investigate Gassendi's influence on modern philosophy and science in general. The growing interest in the European research into Gassendi's ideas seems to confirm our hopes.

\section{Bibliography}

Descartes René. 1958. Medytacje o pierwszej filozofii wraz z Zarzutami uczonych mężów i Odpowiedziami autora oraz Rozmowa z Burmanem. Tłum. zbiorowe. Warszawa: PWN.

Descartes René. 1998. List do Voetiusa. Tłum. Joanna Usakiewicz. Warszawa: Wydawnictwo Naukowe PWN.

Descartes René. 2005. Zarzuty i odpowiedzi późniejsze. Korespondencja z Hyperaspistesem, Arnauldem i Moréem. Tłum. Jerzy Kopania. Kęty: Wydawnictwo Antyk.

9 Thomas M. Lennon, The Battle of the Gods and Giants. The Legacies of Descartes and Gassendi, 1655-1715, (Princeton: Princeton University Press, 1993). 
Gassendi Pierre. 2017. Dociekania metafizyczne, czyli wątpliwości i zastrzeżenia wobec metafizyki René Descartes'a i wobec jego odpowiedzi. Tłum. Joanna Usakiewicz. Kęty: Wydawnictwo Marek Derewiecki.

Gassendi Pierre. Logika, w przekładzie Ludwika Chmaja, z dodaniem Wstępu do Zarysu filozofii, w przekładzie Leona Joachimowicza. Warszawa: PWN, 1964.

Kołakowski Leszek. 1964. „Piotr Gassendi. Chrześcijanin, materialista, sceptyk”. W: Pierre Gassendi, Logika, w przekładzie Ludwika Chmaja, z dodaniem Wstępu do Zarysu filozofii, w przekładzie Leona Joachimowicza, VII-LVIII. Warszawa: PWN.

Kopania Jerzy. 2015. „O powodach irytacji Kartezjusza stanowiskiem Gassendiego”. Idea. Studia nad struktura i rozwojem pojęć filozoficznych XXVII: 13-40.

Lennon Thomas M. 1993. The Battle of the Gods and Giants. The Legacies of Descartes and Gassendi, 1655-1715. Princeton: Princeton University Press.

Usakiewicz Joanna. 2017. „Polemiczna łacina Descartes’a na podstawie Listu do Voetiusa". Meander (72): 33-66.

Usakiewicz Joanna. 1998. „Problem uczciwości retorycznej i odpowiedzialności za słowo w praktyce polemicznej René Descartes'a”. Przegląd Humanistyczny 1(346), Rok XLII: s. 137-148.

\section{Abstract \\ Polish Translation of Gassendi's Polemic with Descartes. Description of the Completed Research Project}

This article describes the already completed research project that involved translating into Polish the work by Pierre Gassendi Disquisitio metaphysica, which is a polemic with René Descartes' Meditations on First Philosophy. The description consists of the aim of the project, translation methodology as well as the content summary and the major theses of the introduction to the translation. The project was financed by the National Science Centre under the decision DEC-2013/09/B/ HS1/01994.

Keywords: Gassendi, Descartes, polemic, metaphysics, cognition 


\section{Streszczenie}

\section{Polski przekład polemiki Gassendiego z Descartes’em.}

Opis zrealizowanego projektu badawczego

Artykuł zawiera opis zrealizowanego projektu badawczego, którego zakres obejmował dokonanie polskiego przekładu dzieła Pierre’a Gassendiego Disquisitio metaphysica będącego polemiką z treścią Medytacji o pierwszej filozofii René Descartesa. Opis zwiera omówienie celu projektu, charakterystykę metodologii przekładu oraz streszczenie zawartości i głównych tez Wstępu do przekładu. Projekt został sfinansowany ze środków Narodowego Centrum Nauki przyznanych na podstawie decyzji numer DEC-2013/09/B/HS1/01994.

Słowa kluczowe: Gassendi, Descartes, polemika, metafizyka, poznanie 